\title{
ANALISIS FAKTOR-FAKTOR YANG MEMPENGARUHI LOYALITAS KARYAWAN PADA PT. PLASA TELKOM GROUP SINGARAJA
}

\author{
Komang Sri Sutriniasih \\ Jurusan Pendidikan Ekonomi \\ Universitas Pendidikan Ganesha \\ Singaraja, Indonesia \\ e-mail: komangsrisutriniasih@gmail.com
}

\begin{abstract}
Abstrak
Penelitian ini bertujuan untuk mengetahui faktor-faktor yang mempengaruhi loyalitas karyawan dan faktor yang paling dominan mempengaruhi loyalitas karyawan pada PT. Plasa Telkom Group Singaraja. Jenis penelitian ini merupakan penelitian deskriptif eksplorasi. Subjek penelitian adalah karyawan PT. Plasa Telkom Group Singaraja dan obyek penelitian adalah loyalitas karyawan. Data dikumpulkan dengan metode kuesioner dan dianalisis menggunakan analisis faktor dengan bantuan SPSS 16.0 for Windows. Hasil penelitian menunjukkan bahwa terdapat 14 faktor yang mempengaruhi loyalitas karyawan pada PT. Plasa Telkom Group Singaraja, namun hanya 4 faktor yang mempegaruhi loyalitas karyawan yang menunjukkan eigenvalue $>1$. Keempat faktor tersebut yaitu karakteristik pribadi, karakteristik pekerjaan, karakteristik perusahaan, dan pengalaman kerja kemudian faktor yang paling dominan pengaruhnya terhadap loyalitas karyawan pada PT. Plasa Telkom Group Singaraja adalah faktor status perkawinan, faktor jati diri tugas, faktor sumber daya organisasi dan faktor penguasaan terhadap pekerjaan.
\end{abstract}

Kata kunci: faktor-faktor Loyalitas Karyawan

\section{Abstract}

This research was aimed to identify the factors that affect employee loyalty and the most dominant factors affect employee loyalty at PT. Plasa Telkom Group Singaraja. This research was descriptive exploratory research. Research subject in this research was PT. Plasa Telkom Group Singaraja employee and the object of research was employee loyalty. The data collected by questionnaires methods and analyzed by factor analysis using SPSS 16.0 for Windows. The results showed that there are 14 factors that affect employee loyalty at PT. Plasa Telkom Group Singaraja, but only 4 factors that affect the employee loyalty that shows eigenvalue $>1$. The four factors are personal characteristics, job characteristics, corporate characteristics, and work experience then the most dominant factor influence on employee loyalty at PT. Plasa Telkom Group Singaraja is the factor of marital status, task identity factor, organizational resource factor and occupational control factor.

Keywords: Employee Loyalty factors

\section{PENDAHULUAN}

Keberhasilan perusahaan tidak lepas dari sumber daya manusia (SDM) itu sendiri. Sumber Daya Manusia (SDM) senantiasa mempunyai kedudukan yang penting dalam sebuah perusahaan, inti dari tujuan para pekerja dalam pekerjaannya adalah mencari kesejahteraan, baik material maupun spiritual. Pembangunan ketenagakerjaan mempunyai banyak dimensi dan keterkaitan. Keterkaitan itu tidak hanya pada kepentingan tenaga kerja tetapi juga keterkaitan dengan kepentingan pengusaha, pemerintah dan masyarakat.

Sumber Daya Manusia (SDM) memegang peranan yang sangat penting, karena dengan tidak adanya tenaga kerja atau karyawan yang professional dan kompetitif, perusahaan tidak dapat melakukan aktivitasnya secara maksimal meskipun semua peralatan modern yang diperlukan telah 
tersedia. Melihat sangat pentingnya peranan tenaga kerja sebagai sumber daya manusia dalam proses produksi sehingga diharapkan karyawan akan dapat bekerja lebih produktif dan profesional dengan didorong oleh rasa aman dalam melakukan segala aktivitasnya, perlu diperhatikan ketentuan-ketentuan yang berkenaan dengan keberadaan sumber daya manusia sebagai pekerja dalam perusahaan yang sedikit banyak menentukan tercapai atau tidaknya tujuan perusahaan. Bekerja merupakan salah satu jalan seseorang meraih aktualisasi diri serta memenuhi kebutuhan hidupnya. Dalam hal bekerja, salah satu aspek penting yang diperlukan oleh karyawan adalah loyalitas kerja.

Trianasari (2005) menyebutkan beberapa aspek loyalitas yang menitikberatkan terhadap apa yang dilakukan karyawan untuk perusahaan antara lain: taat pada peraturan, tanggung jawab pada perusahaan, kemauan untuk bekerja sama, rasa memiliki dan hubungan antarpribadi. Aspek-aspek loyalitas tersebut, baik yang merupakan proses psikologis individu maupun dalam proses bekerja tersebut di atas akan sering mempengaruhi untuk membentuk loyalitas, yaitu dorongan yang kuat untuk tetap menjadi anggota perusahaan, kepercayaan yang pasti, penerimaan penuh atas nilai-nilai perusahaan, taat pada peraturan yang berlaku, rasa tanggung jawab yang tinggi dan sikap kerja yang positif. Loyalitas merupakan kondisi psikologis yang mengikat karyawan dan perusahaannya. Lebih lanjut Gilbert (2006) menyatakan bahwa loyalitas adalah saling mengenal antaranggota dalam kelompoknya yang besar, perasaan memiliki yang kuat, memiliki teman yang banyak dalam perusahaan, dan lebih luas lagi di luar perusahaan terdapat hubungan pribadi selama mereka menjalani pekerjaan, sedangkan menurut Steers \& Porter (2003), loyalitas kerja akan tercipta apabila karyawan merasa tercukupi dalam memenuhi kebutuhan hidup dari pekerjaannya, sehingga mereka betah bekerja dalam suatu perusahaan.

Yuliandri (2005) menegaskan bahwa faktor yang mempengaruhi loyalitas kerja karyawan adalah adanya fasilitas-fasilitas kerja, tunjangan kesejahteraan, suasana kerja serta upah yang diterima dari perusahaan. Sasmitaningrum (2008) mengemukakan timbulnya loyalitas kerja dipengaruhi oleh faktor-faktor : karakteristik pribadi, meliputi: usia, masa kerja, jenis kelamin, tingkat pendidikan, prestasi yang dimiliki, ras, dan sifat kepribadian; karakteristik pekerjaan, meliputi: tantangan kerja, stres kerja, kesempatan untuk berinteraksi sosial, job enrichment, identifikasi tugas, umpan balik tugas, dan kecocokan tugas; karakteristik desain perusahaan, yang dapat dilihat dari sentralisasi, tingkat formalitas, tingkat keikutsertaan dalam pengambilan keputusan, paling tidak telah menunjukkan berbagai tingkat asosiasi dengan tanggungjawab perusahaan, ketergantungan fungsional maupun fungsi kontrol perusahaan; pengalaman yang diperoleh dalam perusahaan, yaitu internalisasi individu terhadap perusahaan setelah melaksanakan pekerjaan dalam perusahaan tersebut meliputi sikap positif terhadap perusahaan, rasa percaya terhadap perusahaan sehingga menimbulkan rasa aman, merasakan adanya kepuasan pribadi yang dapat dipenuhi oleh perusahaan. Loyalitas karyawan pada suatu perusahaan ditunjukan dengan komitmen karyawan di dalam perusahaan, komitmen dalam berorganisasi dapat terbentuk karena adanya beberapa faktor yaitu dari dari diri sendiri dan organisasi.

PT. Plaza Telkom Group Singaraja adalah Badan Usaha Milik Negara (BUMN) telekomunikasi serta penyeleggaraan layanan telekomunikasi dan jaringan terbesar di Indonesia. Telkom Group melayani jutaan pelanggan di seluruh Indonesia dengan rangkaian lengkap layanan telekomunikasi yang mencangkup sambungan telepon kabel tidak 
bergerak dan telepon nirkabel tidak bergerak, komunikasi seluler, layanan jaringan dan interkoneksi serta layanan internet dan komunikasi data. Tekom Group juga menyediakan berbagai layanan di bidang inpormasi, media dan edutaiment, termasuk cloud-based and server-based managed services, layanan e-Payment dan IT enabler, eCommerce dan layanan portal lainnya. Salah satu cabang mereka berada di jalan Telkom, Kecamatan Buleleng, Kabupaten Buleleng, Bali, berdasarkan penelitian awal yang peneliti lakukan, menemukan bahwa loyalitas karyawan perusahaan PT. Telkom Plaza Group Singaraja dalam catur wulan keduan tahun 2016 memiliki loyalitas di bawah standar ketetapan perusahaan.

Dari uraian latar belakang permasalahan tersebut, maka peneliti tertarik melakukan penelitian yang berjudul Analisis Faktor-Faktor yang Mempengaruhi Loyalitas Karyawan Pada PT. Plasa Telkom Group Singaraja. Tujuan penelitian ini adalah untuk mengetahui Faktor-faktor apa saja yang mempengaruhi loyalitas karyawan pada PT. Plasa Telkom Group Singaraja dan Faktor yang paling dominan mempengaruhi loyalitas karyawan pada PT. Plasa Telkom Group Singaraja.

\section{DESKRIPSI TEORI DAN PENELITIAN TERDAHULU}

Hasibuan (2005) menyatakan bahwa loyalitas atau kesetiaan merupakan salah satu unsur yang digunakan dalam penilaian karyawan yang mencakup kesetiaan terhadap pekerjaannya, jabatannya dan organisasi. Kesetiaan ini dicerminkan oleh kesediaan karyawan menjaga dan membela organisasi di dalam maupun di luar pekerjaan dari rongrongan orang yang tidak bertanggungjawab. Lebih lanjut Poerwopoespito (2004), menyebutkan bahwa loyalitas kepada pekerjaan tercermin pada sikap karyawan yang mencurahkan kemampuan dan keahlian yang dimiliki, melaksanakan tugas dengan tanggung jawab, disiplin serta jujur dalam bekerja.
Loyalitas kerja akan tercipta apabila karyawan merasa tercukupi dalam memenuhi kebutuhan hidup dari pekerjaannya, sehingga meraka betah bekerja dalam suatu perusahaan. Steers \& Porter (2003) menyatakan bahwa timbulnya loyalitas kerja dipengaruhi oleh Karakteristik Pribadi, Karakteristik Pekerjaan, Karakteristik Perusahaan dan Pengalaman Kerja. Adapun beberapa penelitian terdahulu yang digunakan sebagai perbandingan dan acuan dalam pembuatan penelitian ini. Penelitian terdahulu yang digunakan dilakukan oleh Hermawan (2013) degan judul "Analisis Faktor-Faktor Yang Menentukan Loyalitas Karyawan Pada PT. Inti Buana Permai Denpasar Bali" yang hasilnya diperoleh bahwa terdapat 4 (empat) faktor yang menentukan loyalitas karyawan pada PT. Inti Buana Permai Denpasar Bali yaitu faktor kompensasi, faktor tanggung jawab, faktor disiplin dan faktor partisipasi sedangkan variabel yang dominan menentukan loyalitas karyawan adalah variabel tunjangan transportasi, absensi serta inisiatif dan kreatif. Selanjutnya penelitian yang dilakukan oleh Mardalis (2012) yang berjudul "Faktor-Faktor Penentu yang Mempengaruhi Loyalitas Kerja Karyawan" yang hasilnya diperoeh bahwa motivasi kerja, kompensasi dan manajemen karir berpengaruh terhadap loyalitas kerja.

\section{METODE}

Jenis penelitian yang digunakan dalam penelitian ini adalah penelitian deskriptif eksplorasi. Menurut Sugiyono (2014) menyatakan bahwa penelitian deskriptif adalah rancangan penelitian yang mendeskripsikan fenomena yang terjadi dilapangan dengan apa adanya tanpa ada rekayasa. Rancangan penelitian deskriptif digunakan untuk memperoleh data yang jelas, obyektif, sistematis dan cermat mengenai faktafakta aktual. Penelitian ini dilakukan untuk memperoleh gambaran mengenai faktor - faktor yang mempengaruhi loyalitas karyawan dan untuk mengetahui faktor yang dominan 
mempengaruhi loyalitas karyawan pada PT. Paza Telkom Group Singaraja. Data dalam penelitian ini dianalisis dengan menggunakan analisis faktor.

Populasi merupakan suatu wilayah generalisasi yang terdiri atas objek dan subjek yang mempunyai kualitas dan karakteristik tertentu yang ditetapkan oleh peneliti untuk dipelajari dan kemudian ditarik kesimpulan (Sugiyono, 2014). Populasi pada penelitian ini adalah seluruh karyawan Pada PT. Plasa Telkom Group Singaraja pada tahun 2016 yang berjumlah 123 orang, sehingga populasi akan dijadikan sampel mengingat jumlah populasi masih relatif kecil dan masih dalam kemampuan peneliti.

Metode pengumpulan data yang dipergunakan dalam penelitian ini adalah kuesioner atau angket. Data yang telah dikumpulkan digunakan sistem skor, dimana jawaban pertanyaan diberi skor dengan menggunakan skala likert. Skala likert merupakan skala yang digunakan untuk mengukur, sikap, pendapat, dan persepsi seseorang atau sekelompok orang tentang fenomena sosial (Sugiyono, 2014). Setiap pernyataan disediakan 5 (lima) alternatif jawaban, seperti nampak pada Tabel 1.

Tabel 1. Tipe Jawaban Kuesioner dengan Skala Likert

\begin{tabular}{clc}
\hline No & \multicolumn{1}{c}{ Jawaban } & Nilai Skala Likert \\
\hline 1 & Sangat Tidak Setuju (STS) & 1 \\
2 & Tidak Setuju (TS) & 2 \\
3 & Cukup Setuju (CS) & 3 \\
4 & Setuju (S) & 4 \\
5 & Sangat Setuju (SS) & 5 \\
\hline
\end{tabular}

Kuesioner sebagai instrumen pengumpulan data sebelum digunakan untuk mengumpulkan data di lapangan terlebih dahulu harus diuji tingkat validitas dan reliabilitasnya yang akan diujikan kepada 30 responden. Validitas adalah untuk melihat kecermatan alat ukur, yaitu mengukur apa yang akan diukur. Pengujian validitas dalam penelitian ini dilakukan dengan menggunakan Person Correlation yang terdapat dalam program SPSS 16.0 for Windows. Suatu pertanyaan dikatakan valid jika tingkat signifikasinya di bawah 0,05 (Ghozali, 2011). Reliabilitas berkaitan dengan keterandalan suatu indikator. Informasi yang ada pada indikator ini tidak berubah-ubah, atau bisa disebut dengan kosisten. Pengujian realibilitas dalam penelitian ini dilakukan dengan menggunakan Alpha Cronbach yang terdapat dalam program SPSS 16.0 for Windows. Suatu instrumen dikatakan reliabel jika memiliki nilai Alpha Cronbach $>0,70$ (Ghozali, 2011).

$$
\text { Hasil pengujian Validitas }
$$

menunjukkan bahwa terdapat empat indikator yang memiliki nilai dibawah $r$ tabel dan tidak signifikan sehingga keempat indikator pernyataan tersebut tidak digunakan dalam analisis faktor sedangkan hasil pengujian rehabilitasi menunjukkan bahwa semua instrumen penelitian memiliki nilai cronbach alpha $>0,60$ sehingga semua variabel adalah reliabel.

Metode analisis data dalam penelitian ini menggunakan analisis faktor. Suliyanto (2005:114) menyatakan "analisis faktor adalah suatu teknik untuk menganalisis tentang saling ketergantungan (interdependence) dari beberapa variabel secara simultan dengan tujuan untuk menyederhanakan dari bentuk hubungan antara beberapa variabel yang diteliti menjadi sejumlah faktor yang lebih sedikit dari variabel yang diteliti". Menurut Suliyanto (2005) analisis faktor terdiri lima tahap, yaitu Membuat matrik, Menentukan jumlah factor, Rotasi Faktor, Interpretasi faktor dan Menentukan ketepatan model. 
Masing-masing tahap tersebut dapat dijelaskan sebagai berikut.

Pertama, Membuat matrik. Semua data yang masuk dan diolah akan menghasilkan matrik korelasi. Matrik korelasi dapat diidentifikasikan variabelvariabel tertentu yang tidak mempunyai korelasi dengan variabel yang lain, sehingga dapat dikeluarkan dari analisis. Untuk menguji ketepatan model analisis faktor, maka dapat digunakan Barlett's test of Sphericity yang dipakai untuk menguji bahwa variabel-variabel dalam sampel berkorelasi. Hasil Barlett's test of Sphericity menunjukkan apakah hubungan antara variabel-variabel signifikan atau tidak. Statistik lain yang berguna adalah pengukuran kelayakan sampel Kaiser Meyer Olkin (KMO). Analisis faktor dianggap layak jika besaran KMO nilainya minimal 0,50. Besaran ini digunakan untuk mengukur derajat korelasi antar variabel dengan kriteria Measure of Sampling Adequacy $(\mathrm{MSA}) \geq 0,50$.

Kedua, Menentukan jumlah faktor. Variabel disusun kembali berdasarkan pada korelasi hasil langkah pada butir dua untuk menentukan faktor yang diperlukan untuk mewakili data. Untuk menentukan berapa faktor yang dapat diterima secara empiric dapat dilakukan berdasarkan besarnya eigenvalue setiap faktor, semakin representatif faktor tersebut untuk mewakili sekelompok variabel. Faktor-faktor ini yang dipilih adalah faktor yang mempunyai eigenvalue sama dengan atau lebih dari satu.

Ketiga, Rotasi Faktor. Hasil penyederhanaan faktor dalam matrik faktor memperlihatkan hubungan antara faktor dengan variabel individu, tetapi dalam faktor-faktor tersebut terdapat banyak variabel yang berkorelasi sehingga sulit diinterpretasikan. Dengan menggunakan rotasi faktor matrik, matrik faktor ditranspormasikan ke dalam matrik yang lebih sederhana sehingga mudah untuk diinterpretasikan. Dalam perilaku ini digunakan rotasi varimax.

Keempat, Interpretasi faktor.
Interpretasi faktor dilakukan dengan mengelompokkan variabel yang mempunyai faktor loading tinggi ke dalam faktor tersebut. Untuk menginterpretasikan hasil penelitian ini, faktor loading minimal 0,5. Variabel yang mempunyai faktor loading kurang dari 0,5 dikeluarkan dari model.

Kelima, Menentukan ketepatan model. Tahap terakhir dari analisis faktor adalah mengetahui apakah model mampu menjelaskan dengan baik. Fenomena yang ada perlu diuji dengan teknik Principal Component Analisis (PCA) yaitu dengan melihat jumlah resudial antara korelasi yang diamati dengan korelasi yang direproduksi.

$$
\text { Data yang didapat dari }
$$

kuesioner masih berupa data ordinal, sedangkan analisis data yang dipakai untuk membuktikan kebenaran pengujian analisis faktor mengisyaratkan minimal data interval, maka data ordinal tersebut perlu ditingkatkan skala pengukurannya menjadi skala interval melalui "Method of Succestive Interval" dari (Riduwan, 2008) dengan langkah sebagai berikut. Ambil data ordinal dari kuesioner, untuk setiap pertanyaan hitung proporsi jawaban untuk setiap kategori jawaban dan hitung proporsi kumulatifnya, menghitung nilai $Z$ (tabel distribusi normal) untuk setiap proporsi kumulatif (untuk data $n>30$ dianggap mendekati luas daerah di bawah kurve normal), menghitung nilai densitas untuk setiap proporsi kumulatif dengan memasukkan nilai $Z$ pada rumus distribusi normal, menghitung nilai skala dengan rumus.

Menentukan nilai transformasi (nilai untuk skala interval) dengan menggunakan rumus nilai transformasi $=$ Nilai Skala + Nilai Skala Minimal +1

$$
\text { Sesuai hipotesis konseptual }
$$
yang diajukan, dimana hipotesis konseptual tersebut merupakan faktor atau dimensi yang menjelaskan variabel utama yang digambarkan dalam sebuah paradigma. Faktor atau dimensi dalam menjelaskan variabel utama yaitu faktor karakteristik pribadi, faktor karakteristik pekerjaan, faktor karakteristik perusahaan, dan faktor pengalaman 
kerja. Hipotesis konseptual akan dianalisis dengan menggunakan analisis faktor dengan langkah-langkah Menguji matriks korelasi menggunakan menggunakan Barlett's test of Sphericity dengan koefisien KMO yang telah tersedia dalam SPSS 16.0 for Windows. Jika hasil pengujian statistik Barlett's test of Sphericity signifikan dan hasil perhitungan koefisien $\mathrm{KMO}>0,50$ maka persyaratan pengujian analisis faktor untuk menentukan faktor yang menjelaskan loyalitas.

Untuk menentukan banyaknya faktor yang menjelaskan loyalitas dapat dilakukan dengan memilih faktor atau komponen utama yang memiliki parameter akar karakteristik terkecil (eigenvalue) $>1$, sedangkan untuk menentukan dimensi atau factor loyalitas menggunakan jasa digunakan faktor atau komponen utama yang paling mendominasi, maka akan digunakan parameter koefisien varimax rotation dari dimensi atau faktor rendahnya motivasi kerja karyawan yang paling mendekati +1 atau mendekati - 1 .

\section{HASIL DAN PEMBAHASAN \\ Hasil Penelitian \\ Matrik Korelasi}

Langkah pertama yang harus dilakukan dalam analisis faktorial adalah menilai variabel mana saja yang layak untuk dimasukkan dalam analisis selanjutnya. Matriks korelasi dapat dilihat pada output analisis faktor yaitu correlation matriks. Syarat correlation matriks terdiri atas determination of correlation matrix, Kaiser-Meyer-Oilkin (KMO) dan Measure Of Sampling Adequacy (MSA). Hasil dari persyaratan correlation matriks diantaranya adalah: Uji Determination of Correlation Matrix

Analisis faktor mensyaratkan bahwa variabel yang diidentifikasikan harus saling berhubungan yang ditunjukkan dengan nilai determination of correlation matrix. Matriks korelasi dikatakan mantra variabel saling terkait apabila determinan bernilaimendekati nilai 0 (nol). Hasil analisis determination of correlation matriks pada hasil analisis faktor menunjukkan nilai sebesar 0,806E-011. Hasil menunjukkan bahwa nilai determination of correlation matriks sebesar, dimana nilai tersebut mendekati nilai 0 (nol) sehingga dapat disimpulkan bahwa matriks korelasi antar variabel saling terkait.

Uji Kaiser-Meyer-Oilkin (KMO)

Uji Kaiser-Meyer-Olkin (KMO)

and Bartlett's Test of Sphericity bertujuan untuk menguji derajat interkorelasi antara variabel dan ketepatan pemakaian analisis faktor serta untuk mengetahui kecukupan sampel atau pengukuran kelayakan sampel pada analisis faktor dengan syarat jika nilai $\mathrm{KMO}>0,5$ dan uji Bartlett's Test of Sphericity apabila nilai signifikan < 5\%. Adapun hasil Uji KMO and Bartlett's Test seperti nampak pada Tabel

Tabel 2. KMO and Bartlett's Test

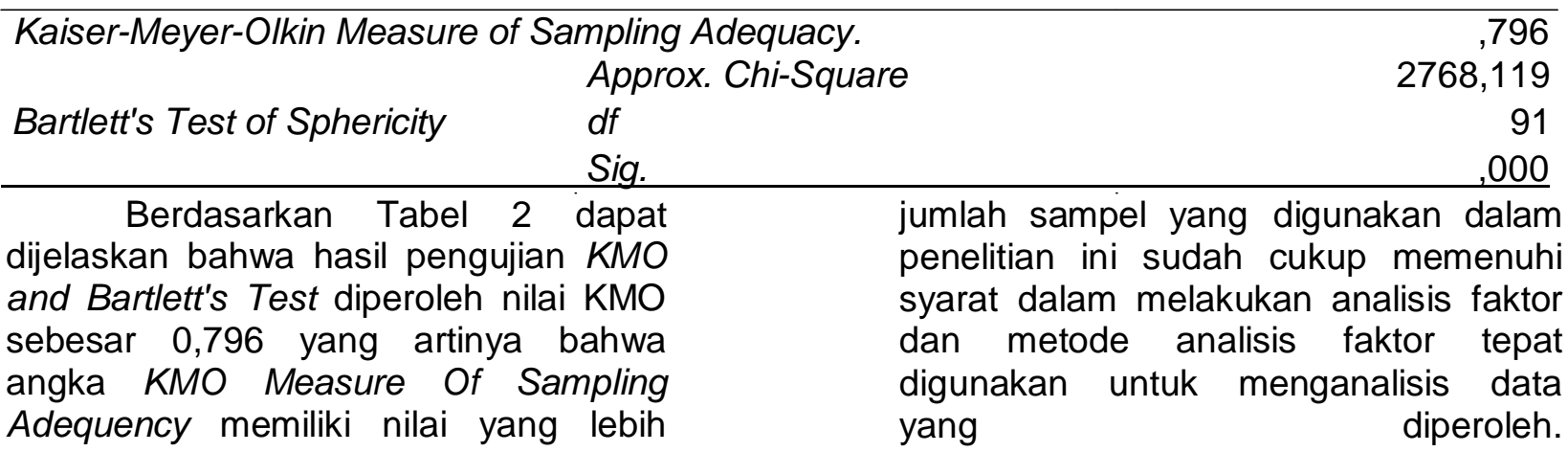

jumlah sampel yang digunakan dalam penelitian ini sudah cukup memenuhi syarat dalam melakukan analisis faktor dan metode analisis faktor tepat digunakan untuk menganalisis data 
Pengujian Barlett's Test of Sphericity menunjukkan hasil pengujian yang signifikan pada taraf nyata 0,000 dengan approximation Chi-Square = 2768,119 dan df $=91$. Angka ini digunakan untuk menguji apakah matriks korelasi merupakan matriks identitas atau bukan. Karena nilai signifikansi lebih kecil dari 0,05 atau 5\% maka matriks korelasi yang diuji bukan merupakan matriks identitas.

Uji Measure Of Sampling Adequacy (MSA)
Pengujian Measure of Sampling Adequacy (MSA) dimana tiap variabel dianalisis untuk mengetahui variabel mana yang dapat diproses lebih lanjut atau dikeluarkan. Untuk dapat diproses lebih lanjut setiap variabel harus memiliki MSA > 0,5. Nilai MSA terdapat dalam tabel Anti Image Matrice pada bagian Anti Image Correlation yaitu angka korelasi yang bertanda "a" dengan arah diagonal dari kiri atas ke kanan bawah. Hasil MSA dapat ditampilkan pada Tabel 4.

Tabel 3. Hasil Analisis Measure of Sampling Adequacy (MSA)

\begin{tabular}{|c|c|c|c|}
\hline Variabel & Nilai MSA & Syarat MSA & Keterangan \\
\hline 1 & 0,812 & $>\overline{0,50}$ & Dapat digunakan untuk analisis faktor \\
\hline 2 & 0,743 & $>0,50$ & Dapat digunakan untuk analisis faktor \\
\hline 3 & 0.646 & $>0,50$ & Dapat digunakan untuk analisis faktor \\
\hline 4 & 0.813 & $>0,50$ & Dapat digunakan untuk analisis faktor \\
\hline 5 & 0,778 & $>0,50$ & Dapat digunakan untuk analisis faktor \\
\hline 6 & 0,731 & $>0,50$ & Dapat digunakan untuk analisis faktor \\
\hline 7 & 0,963 & $>0,50$ & Dapat digunakan untuk analisis faktor \\
\hline 8 & 0,894 & $>0,50$ & Dapat digunakan untuk analisis faktor \\
\hline 9 & 0,842 & $>0,50$ & Dapat digunakan untuk analisis faktor \\
\hline 10 & 0,950 & $>0,50$ & Dapat digunakan untuk analisis faktor \\
\hline 11 & 0,711 & $>0,50$ & Dapat digunakan untuk analisis faktor \\
\hline 12 & 0,719 & $>0,50$ & Dapat digunakan untuk analisis faktor \\
\hline 13 & 0,760 & $>0,50$ & Dapat digunakan untuk analisis faktor \\
\hline 14 & 0,763 & $>0,50$ & Dapat digunakan untuk analisis faktor \\
\hline
\end{tabular}

Berdasarkan Tabel 3, diketahui bahwa variabel-variabel dalam penelitian memiliki MSA $>0,50$, sehingga tidak terdapat variabel yang dikeluarkan dari model karena ke-14 variabel sesuai dengan kriteria yang ditentukan yaitu nilai MSA $>0,50$ sehingga variabel dapat dianalisis secara keseluruhan dan dapat dilanjutkan.

\section{Penentuan Jumlah Faktor}

Untuk menentukan banyaknya faktor yang mempengaruhi atau yang mampu menjelaskan faktor yang mempengaruhi loyalitas karyawan, maka dilakukan ekstraksi faktor.
Ekstraksi faktor dapat dijelaskan oleh total persentase varians dari masingmasing faktor utama. Nilai Total Variance Explained digunakan untuk mengetahui banyaknya faktor yang terbentuk yang dapat dilakukan dengan memilih faktor atau komponen utama yang memiliki parameter akar karakteristik terkecil (eigenvalue) $>1$. Susunan egine value diurutkan dari yang terbesar sampai yang terkecil. Berdasarkan hasil analisis faktor, maka untuk mengetahui faktor yang memiliki eigenvalue $>1$ dapat dilihat pada tabel 4. 
Tabel 4. Hasil Analisis Total Variance Expained

\begin{tabular}{lrrrrrr}
\hline Component & \multicolumn{3}{c}{ Initial Eigenvalues } & \multicolumn{3}{c}{ Extraction Sums of Squared Loadings } \\
\cline { 2 - 7 } & Total & $\begin{array}{c}\text { \% of } \\
\text { Variance }\end{array}$ & $\begin{array}{c}\text { Cumulative } \\
\%\end{array}$ & Total & $\begin{array}{c}\text { \% of } \\
\text { Variance }\end{array}$ & Cumulative \% \\
\hline 1 & 7,730 & 55,213 & 55,213 & 7,730 & 55,213 & 7,730 \\
2 & 2,619 & 18,710 & 73,923 & 2,619 & 18,710 & 2,619 \\
3 & 1,896 & 13,541 & 87,464 & 1,896 & 13,541 & 1,896 \\
4 & 1,630 & 4,497 & 91,961 & 1,630 & 4,497 & 1,630 \\
\hline
\end{tabular}

Extraction Method: Principal Component Analysis.

Berdasarkan Tabel 4 dapat

dijelaskan bahwa terdapat empat faktor yang memiliki eigenvalue $>1$ dengan total Extraction Sums of Squared Loadings ke empat faktor tersebut adalah 91,961\%. Dengan demikian $91,961 \%$ dari seluruh variabel yang ada, dapat dijelaskan empat faktor mempengaruhi. Ke empat faktor yang mempengaruhi loyalitas karyawan pada PT. Plasa Telkom Group Singaraja antar lain faktor ke-1 adalah karakteristik pribadi, faktor ke-2 adalah karakteristik pekerjaan, faktor ke-3 adalah karakteristik perusahaan, dan terakhir faktor ke-4 adalah pengalaman kerja, dengan kata lain empat faktor tersebut mampu menjelaskan pengaruhnya sebesar 91,961\% terhadap faktor loyalitas karyawan dan sisanya sebesar $8,039 \%$ dipengaruhi oleh faktor lain.

\section{Rotasi Faktor}

Setelah semua faktor memiliki nilai yang mencukupi, tahap selanjutnya adalah melakukan proses inti dari analisis faktor, yaitu melakukan ekstraksi terhadap sekumpulan variabel yang sudah ada sehingga terbentuk satu atau beberapa faktor. Rotasi faktor dilakukan untuk mempermudah intrepretasi dalam menentukan variabelvariabel mana saja yang tercantum dalam suatu faktor. Dalam penelitian ini digunakan rotasi varimax. Interpretasi faktor dilakukan dengan mengelompokkan variabel yang mempunyai faktor loading tertinggi di dalam faktor tersebut. untuk menginterpretasikan variabel dalam penelitian ini, minimal faktor loadingnya bernilai 0,5 . Hasil rotasi dari variabelvariabel tersebut dapat dilihat pada Tabel

Tabel 5. Hasil Roated Component Matrix

\begin{tabular}{|c|c|c|c|c|c|}
\hline Faktor & Nama Faktor & Nama Variabel & $\begin{array}{l}\text { Eigen } \\
\text { Valuae }\end{array}$ & $\begin{array}{c}\% \text { Of } \\
\text { Variance }\end{array}$ & $\begin{array}{l}\text { Faktor } \\
\text { Loading }\end{array}$ \\
\hline \multirow[t]{4}{*}{ Faktor 1} & Karakteristik & $x_{13}$ & 7,730 & 55,213 & 0,973 \\
\hline & Pribadi & $x_{1} 2$ & & & 0,938 \\
\hline & & $X_{1} 4$ & & & 0,903 \\
\hline & & $x_{1} 1$ & & & 0,884 \\
\hline \multirow[t]{5}{*}{ Faktor 2} & Karakteristik & $x_{1} 6$ & 2,619 & 18,710 & 0,924 \\
\hline & pekerjaan & $X_{1} 8$ & & & 0,913 \\
\hline & & $X_{1} 5$ & & & 0,907 \\
\hline & & $X_{1.7}$ & & & 0,885 \\
\hline & & $\mathrm{X}_{1.9}$ & & & 0,855 \\
\hline \multirow[t]{3}{*}{ Faktor 3} & Karakteristik & $X_{1.10}$ & 1,896 & 13,541 & 0,912 \\
\hline & perusahaan & $X_{1.12}$ & & & 0,910 \\
\hline & & $X_{1.11}$ & & & 0,862 \\
\hline Faktor 4 & Pengalaman kerja & $X_{1.4}$ & 1,630 & 4,494 & $0,908 s$ \\
\hline & & $X_{1} 3$ & & & 0,879 \\
\hline
\end{tabular}


Berdasarkan Tabel 5 dapat diketahui bahwa ke-14 variabel memiliki nilai faktor loading $>0,50$, sehingga terkelompokkan menjadi 4 (empat) faktor. ini berarti faktor-faktor yang bisa mempengaruhi loyalitas karyawan pada PT. Plasa Telkom Group Singaraja dapat dijelaskan dari keempat faktor tersebut. Faktor ke-1 adalah karakteristik pribadi, faktor ke-2 adalah karakteristik pekerjaan, faktor ke-3 adalah karakteristik perusahaan, dan terakhir faktor ke-4 adalah pengalaman kerja.

Keempat faktor tersebut mampu menjelaskan pengaruhnya sebesar $91,961 \%$ terhadap loyalitas karyawan dan sisanya sebesar 8,039\% dipengaruhi oleh faktor lain, sehingga disimpulkan bahwa usia, jenis kelamin, status perkawinan, masa kerja, keragaman keterampilan, jati diri tugas, signifikansi tugas, otonomi, umpan balik, sumber daya organisasi, iklim organisasi, struktur organisasi, masa kerja, dan tingkat pengetahuan mampu menjelaskan loyalitas karyawan PT Plasa Telkom Group Singaraja.

\section{Interpretasi Faktor}

Interpretasi faktor dilakukan dengan mengelompokkan variabelvariabel yang mempunyai loading faktor (korelasi) minimal 0,50, dimana semakin tinggi loading faktor berarti semakin erat hubungan antara variabel dengan faktor tersebut. Sujarweni (2016) menyatakan bawa "Nilai loading faktor hendaknya tidak kurang dari 0,50 ", sehingga berdasarkan hasil roated component matriks diketahui bahwa ke-14 variabel yang membentuk 4 (empat) faktor dapat digunakan untuk analisis selanjutnya. Adapun penjelasan masing-masing faktor serta variabel yang dominan mempengaruhi loyalitas karyawan pada PT. Plasa Telkom Group Singaraja secara rinci dapat dijelaskan sebagai berikut.

Faktor karakteristik pribadi memiliki eignvalue sebesar 7,730 dan nilai percentage of variance yang mempengaruhi loyalitas karyawan pada PT. Plasa Telkom Group Singaraja adalah sebesar 55,213\%. Faktor Karakteristik pekerjaan

Faktor karakteristik pekerjaan memiliki eignvalue sebesar 2,619 dan nilai percentage of variance yang mempengaruhi loyalitas karyawan pada PT. Plasa Telkom Group Singaraja adalah sebesar $18,710 \%$.

Faktor karakteristik perusahaan memiliki eignvalue sebesar 1,896 dan nilai percentage of variance yang mempengaruhi loyalitas karyawan pada PT. Plasa Telkom Group Singaraja adalah sebesar 13,541\%.

Faktor pengalaman kerja memiliki eignvalue sebesar 1,630 dan nilai percentage of variance yang mempengaruhi loyalitas karyawan pada PT. Plasa Telkom Group Singaraja adalah sebesar $4,497 \%$.

\section{Faktor yang paling dominan mempengaruhi loyalitas karyawan pada PT. Plasa Telkom Group Singaraja}

Berdasarkan hasil analisis faktor dapat dijelaskan faktor-faktor yang dominan mempengaruhi loyalitas karyawan pada PT. Plasa Telkom Group Singaraja adalah :

Faktor karakteristik pribadi dengan variance explained sebesar 7,730 dimana faktor yang paling mendominasi yaitu status perkawinan dengan nilai varimax rotation sebesar 0,973 sehingga dapat disimpulkan bahwa dimensi status perkawinan dominan mempengaruhi loyalitas karyawan pada PT Plasa Telkom Cabang Singaraja.

Faktor karakteristik pekerjaan dengan variance explained sebesar 2,619 dimana faktor yang paling mendominasi yaitu jati diri tugas dengan nilai varimax rotation sebesar 0,924 sehingga dapat disimpulkan bahwa dimensi jati diri tugas dominan mempengaruhi loyalitas karyawan pada PT Plasa Telkom Cabang Singaraja.

Faktor karakteristik perusahaan dengan variance explained sebesar 1,896 dimana faktor yang paling mendominasi yaitu sumber daya organisasi dengan nilai varimax rotation 
sebesar 0,912 sehingga dapat disimpulkan bahwa dimensi sumber daya organisasi dominan mempengaruhi loyalitas karyawan pada PT Plasa Telkom Cabang Singaraja.

Faktor pengalaman kerja dengan variance explained sebesar 1,630 dimana faktor yang paling mendominasi yaitu penguasaan terhadap pekerjaan dengan nilai varimax rotation sebesar 0,908 sehingga dapat disimpulkan bahwa dimensi penguasaan terhadap pekerjaan dominan mempengaruhi loyalitas karyawan pada PT Plasa Telkom Cabang Singaraja.

\section{Pembahasan}

Berdasarkan hasil hasil analisis faktor, maka dalam penelitian ini ditemukan empat belas (14) faktor yang mempengaruhi loyalitas karyawan pada PT. Plasa Telkom Group Singaraja, diantaranya adalah usia, jenis kelamin, status perkawinan, masa kerja, keragaman ketrampilan, jati diri tugas, signifikasi tugas, otonomi, umpan balik, sumber daya organisasi, iklim organisasi, struktur organisasi, tingkat pengetahuan dan penguasaan terhadap pekerjaan yang mampu menjelaskan pengaruhnya sebesar $91,961 \%$ terhadap loyalitas karyawan dan sisanya sebesar $8,039 \%$ dipengaruhi oleh faktor lain, sehingga disimpulkan bahwa usia, jenis kelamin, status perkawinan, masa kerja, keragaman keterampilan, jati diri tugas, signifikansi tugas, otonomi, umpan balik, sumber daya organisasi, iklim organisasi, struktur organisasi, masa kerja, dan tingkat pengetahuan mampu menjelaskan loyalitas karyawan PT Plasa Telkom Group Singaraja.

Berdasarkan pengujian hipotesis konseptual, untuk menentukan faktor loyalitas karyawan yang paling dominan maka digunakan parameter varimax rotation dari dimensi faktor loyalitas karyawan yang paling mendekati +1 atau mendekati - 1 . Nilai yang mendekati 1 diawali oleh nilai 0,5 , sedangkan nilai yang mendekati - 1 diawali oleh - 0,5. Dari hasil rotasi terhadap faktor matriks pada varimax rotation, maka faktor yang paling mendominasi pada keempat komponen utama yang mempengaruhi, yaitu Faktor karakteristik pribadi dengan variance explained sebesar 7,730 dimana faktor yang paling mendominasi yaitu status perkawinan dengan nilai varimax rotation sebesar 0,973 sehingga dapat disimpulkan bahwa dimensi status perkawinan dominan mempengaruhi loyalitas karyawan pada PT Plasa Telkom Cabang Singaraja, Faktor karakteristik pekerjaan dengan variance explained sebesar 2,619 dimana faktor yang paling mendominasi yaitu jati diri tugas dengan nilai varimax rotation sebesar 0,924 sehingga dapat disimpulkan bahwa dimensi jati diri tugas dominan mempengaruhi loyalitas karyawan pada PT Plasa Telkom Cabang Singaraja, Faktor karakteristik perusahaan dengan variance explained sebesar 1,896 dimana faktor yang paling mendominasi yaitu sumber daya organisasi dengan nilai varimax rotation sebesar 0,927 sehingga dapat disimpulkan bahwa dimensi sumber daya organisasi dominan mempengaruhi loyalitas karyawan pada PT Plasa Telkom Cabang Singaraja, Faktor pengalaman kerja dengan variance explained sebesar 1,630 dimana faktor yang paling mendominasi yaitu penguasaaan terhadap pekerjaaan dengan nilai varimax rotation sebesar 0,908 sehingga dapat disimpulkan bahwa dimensi penguasaan terhadap pekerjaan dominan mempengaruhi loyalitas karyawan pada PT Plasa Telkom Cabang Singaraja.

Hasil kajian empiris melalui diskusi dengan pihak manajemen PT Plasa Telkom Singaraja diperoleh hasil bahwa status pernikahan karyawan memaksakan peningkatan tanggung jawab dalam rumah tangga, yang dapat membuat suatu pekerjaan yang tetap menjadi lebih berharga dan penting, sehingga karyawan akan lebih loyal dalam bekerja. Faktor kedua yang dominan mempengaruhi loyalitas karyawan adalah jati diri tugas yang 
memungkinkan karyawan untuk melaksanakan pekerjaan seutuhnya. Para karyawan yang secara individu mengerjakan bagian kecil pekerjaan tidak dapat mengidentifikasi salah satu produk dengan upaya karyawan tersebut. Semakin baik identifikasi tugas maka semakin baik loyalitas karyawan. Faktor ketiga yang mempengaruhi loyalitas karyawan adalah sumber daya organisasi. Sumber daya organisasi penting untuk sebuah pengembangan karir. Sumber daya organisasi merupakan modal utama organisasi, yang dimaksud adalah sumber daya finansial (keuangan), sumber daya waktu dan sumber daya manusia. Apabila sumber daya organisasi diperhatikan dengan baik maka semakin tinggi loyalitas karyawan. Faktor terakhir yang dominan mempengaruhi loyalitas karyawan adalah Penguasaan terhadap pekerjaan dan peralatan. Apabila karyawan mampu mengguasai pekerjaan dan peralatan dengan baik maka keinginan karyawan untuk berhenti akan menurun dan karyawan akan merasa nyaman untuk bekerja sesuai dengan tugas pokok dan fungsi di perusahaan.

\section{SIMPULAN DAN SARAN}

Berdasarkan hasil penelitian dan pembahasan yang telah diuraikan sebelumnya, maka diperoleh kesimpulan bahwa terdapat 14 faktor yang mempengaruhi loyalitas karyawan pada PT. Plasa Telkom Group Singaraja. Hasil tersebut diperoleh berdasarkan analisis total variance expained dari 14 variabel yang dimasukkan untuk dianalisis faktor, hanya terdapat 4 faktor yang mempengaruhi karena dari komponen 1 sampai dengan komponen 4 menunjukkan eigen value > 1 , kemudian Faktor yang paling dominan pengaruhnya dalam loyalitas karyawan pada PT. Plasa Telkom Group Singaraja diantaranya adalah Faktor karakteristik pribadi dimana faktor yang paling mendominasi yaitu status perkawinan, faktor karakteristik pekerjaan dimana faktor yang paling mendominasi yaitu jati diri tugas, faktor karakteristik perusahaan dimana faktor yang paling mendominasi adalah sumber daya organisasi dan faktor pengalaman kerja dimana faktor yang paling mendominasi adalah penguasaan terhadap pekerjaan.

Berdasarkan simpulan penelitian yang telah dipaparkan, maka diajukan saran, yaitu: berkaitan dengan keterbatasan waktu serta instrumen yang digunakan dalam penelitian, maka kepada peneliti lain yang melaksanakan penelitian sejenis disarankan menggunakan instrumen yang berbeda. Dengan demikian, maka akan mendapatkan gambaran yang lebih komprehensif faktor-faktor yang mempengaruhi loyalitas karyawan. Bagi PT. Plaza Telkom Group Singaraja disarankan untuk memperhatikan faktor-faktor yang mempengaruhi loyalitas karyawan tersebut. Sehingga, diharapkan terjadi peningkatan kinerja karyawan.

\section{DAFTAR PUSTAKA}

Churchill, Gilbert A. Jr. 2009. Riset Pemasaran. Jilid I, Edisi kedelapan. Terjemahan Dr.Dwi Kartini Yahya S.E. M.M. Jakarta: Erlangga.

Ghozali, Imam. 2011. Aplikasi Analisis Multivariate Dengan Program SPSS. Semarang: Universitas Diponegoro.

Hasibuan, Malayu SP. 2005. Manajemen Sumber Daya Manusia. Bumi Aksara: Jakarta.

Hermawan, Ketut Andy. 2013. Analisis Faktor-Faktor Yang Menentukan Loyalitas Karyawan Pada PT. Inti Buana Permai Denpasar Bali. Skripsi tidak diterbitkan. Fakultas Ekonomi. Universitas Udayana (UNUD) 
p-ISSN : 2599-1418

e-ISSN : 2599-1426

Kusumo, B.C.S. 2006. Hubungan Antara Persepsi Terhadap Iklim Organisasi dan Kepuasan Imbalan Kerja Dengan Loyalitas Kerja Pada Karyawan. Skripi tidak diterbitkan. Surakarta: Fakultas Psikologi Universitas Muhammadiyah Surakarta.

Mardalis, Ahmad. 2012. Faktor-Faktor Penentu yang Mempengaruhi Loyalitas Kerja Karyawan. Tesis tidak diterbitkan. Program Pascasarjana Magister Manajemen, Universitas Muhammadiyah Surakarta.

Meyer, J.P., Stanley, D.J., Herscovitch, L. \& Topolnytsky, L., 2002. Affective, Continuance and Normative Commitment to The Organisation: A Meta-analysis of Antecedents, Correlates and Consequences. Journal of Vocational Behaviour, 61(1):20-52.

Riduwan. 2011. Dasar-Dasar Statistika. Bandung: Alfabeta

Poerwopoespito. 2004. Mengatasi Krisis Manusia di Perusahaan. Jakarta: Gramedia Widiasarana Indonesia

Sasmitaningrum, Ratna. 2008. "Hubungan antara Persepsi Karyawan Terhadap Manajemen Konflik Dengan Loyalitas Kerja Karyawan". Skripsi tidak diterbitkan. Surakarta: Fakultas Psikologi Universitas Muhammadiyah Surakarta.

Steers, R.M \& Porter, R. W. 2003. Motivation and Work
Jurnal Pendidikan Ekonomi Undiksha

Volume 10 No. 1 Tahun 2018

Behavior. New York: Mc Graw Hill.

Sugiyono. 2014. Metode Penelitian Bisnis. Jakarta: Penerbit CV. Alfabeta,

Sujarweni, Wiratna. 2016. SPSS Untuk Penelitian. Yogyakarta : Pustaka Baru Press

Suliyanto. 2005. Metode Riset Bisnis. Yogyakarta: Andi.

Trianasari, Y. 2005. Hubungan Antara Persepsi Terhadap Insentif dan Lingkungan Kerja dengan Loyalitas Kerja. Skripsi tidak diterbitkan. Surakarta: Fakultas Psikologi Universitas Muhammadiyah Surakarta.

Yuliandri. 2005. Hubungan Antara Persepsi Terhadap Upah dan Jaminan Sosial Dengan Loyalitas Kerja. Skripsi tidak diterbitkan. Surakarta : Fakultas Psikologi UMS. 